\title{
$\alpha$-D-Galactosylation of surface fucoglycoconjugate(s) upon stimulation/activation of murine peritoneal macrophages
}

\author{
JERZY PETRYNIAK \\ Department of Biological Chemistry, University of Michigan, Ann Arbor, Michigan 48109, USA
}

Received August 6th 1991 and revised October 301991

\begin{abstract}
Murine resident macrophages express, on their surface, carbohydrate epitopes which undergo changes during their stimulation/activation as monitored by binding of ${ }^{125} \mathrm{I}$ labelled Evonymus europaea and Griffonia simplicifolia. I-B $\mathrm{B}_{4}$ lectins. Treatment of the stimulated macrophages with coffee bean $\alpha$-galactosidase abolished binding of the GS I-B ${ }_{4}$ isolectin and changed the binding pattern of the Evonymus lectin. The affinity $\left(K_{2}\right)$ of Evonymus lectin for $\alpha$-galactosidase-treated macrophages decreased approximately 23 -fold, from $1.25 \times 10^{8} \mathrm{M}^{-1}$ to $5.5 \times 10^{6} \mathrm{M}^{-1}$. Subsequent digestion of $\alpha$-galactosidase-treated macrophages with $\alpha$-L-fucosidase from Trichomonas foetus, further reduced binding of Evonymus lectin. Resident macrophages showed the same pattern of Evonymus lectin binding, with the same affinity, as $\alpha$-galactosidase-treated, stimulated macrophages. These results, together with a consideration of the carbohydrate binding specificity of the Evonymus lectin which, in the absence of $\alpha$-D-galactosyl groups, requires $\alpha-\mathrm{L}-$ fucosyl groups for binding, indicate the presence, on resident macrophages, of glycoconjugates with terminal $\alpha$-L-fucosyl residues. It is also concluded that during macrophage stimulation/activation $\alpha$-D-galactosyl residues are added to this glycoconjugate and that they form part of the receptor for Evonymus lectin. The same glycoconjugate(s) is/are also expressed on the activated macrophage $1 \mathrm{C}-21$ cell line which exhibits the same characteristics as that of stimulated peritoneal macrophages, i.e., it contains $\alpha$-D-galactosyl end groups and is resistant to the action of trypsin. Both lectins were also specifically bound to Corynaebacterium parvum activated macrophages.
\end{abstract}

Keywords: Macrophage, fucoglycoconjugate, galactosylation

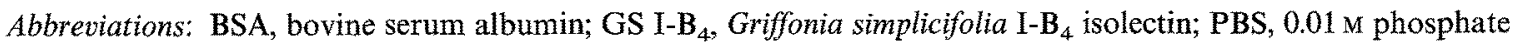
buffer ( $\mathrm{pH} 7.1$ ) with $0.15 \mathrm{M} \mathrm{NaCl}$ (unless stated otherwise this buffer contained $3 \mathrm{~mm}$ azide and was free of divalent cations); PMSF, phenyl methane sulfonyl fluoride; TG, thioglycollate brewers medium.

Macrophage membrane molecules undergo changes during the process of stimulation/activation $[1,2]$ a process that involves glycoconjugate molecules [3-8]. The question arises as to whether these differentiation-related changes in the expression of carbohydrates on the macrophage surface are of biological significance, and whether these carbohydrates play a role in some of the biological functions of these cells, e.g., in cell-cell and cell-milieu interactions.

It has already been observed that the GS I-B ${ }_{4}$ isolectin can promote macrophage-tumour cell interactions leading to enhanced lectin-induced, macrophage-mediated cytotoxicity of the tumour cells in vitro [9]. Other investigators have postulated that carbohydrates, especially $\alpha$-L-fucose, are essential for macrophage-lymphokine interactions as well [10-12]. We have reported the explicit expression of receptors on the surface of stimulated macrophages for lectins of well defined carbohydrate binding specificity, i.e., Datura strammonium, Evonymus europaea and the Griffonia simplicifolia $\mathrm{I}_{-} \mathrm{B}_{4}$ isolectin. Physicochemical parameters for the binding of these lectins to the surface of stimulated macrophages were determined [7].

It has been shown that the receptor(s) for the GS I-B 4 lectin on stimulated macrophages contains terminal nonreducing $\alpha$-D-galactosyl residues [3]. Recently it has been postulated that $\alpha$-D-galactosyl residues may participate in the binding of macrophages to tumour cells [13]. Previous studies demonstrated that inflammatory and activated macrophages show alteration in the amount and surface exposure of specific glycolipids [5]. Mercurio and Robbins [6] showed that the activation of macrophages involves changes in the structure and expression of protein-bound lactosaminoglycans on the macrophage surface.

This report is a continuation of our studies on the expression of glycoconjugates on the surface of macrophages, using lectins as probes. An attempt has been made to answer the question whether glycoconjugate(s) containing $\alpha$-Dgalactosyl groups appear on the macrophage surface $d e$ novo, or whether they are present on resident macrophages 
in their agalacto form and modified during the process of macrophage stimulation/activation. From the lectins specificity we have also tried to deduce the structure of carbohydrate epitopes. The present investigation indicates that different stages of macrophage activation/differentiation can be characterized by specific cell carbohydrate epitopes, unique to each stage, viz. agalacto-fucoglycoconjugates on resident macrophages and their $\alpha$-galactosylated species on stimulated/activated ones.

\section{Materials and methods}

\section{Chemicals}

$\mathrm{Na}^{125} \mathrm{I}$ (carrier free) was from New England Nuclear DuPont, Boston, MA, USA. Chloramine-T and sodium metabisulfite from J. T. Baker Chemical Co., Philipsburg, NJ, USA; dioctyl phthalate and dibutylphthalate from Aldrich Chemical Company, Milwaukee, WI, USA; bovine serum albumin (BSA) from Miles Laboratories, Napierville, IL, USA; Azocoll from Calbiochem, La Jolla, CA, USA; Bio-Gel P-60 (50-100 mesh) from Bio-Rad Laboratories, Richmond, CA, USA; Iodogen from Pierce, Rockford, IL, USA; methyl $\alpha$-D-galactopyranoside and lactose from Pfanstiehl Laboratories, Waukegan, IL, USA.

\section{Enzymes, glycoproteins and lectins}

Trypsin-TPCK was from Worthington Biochemical Corporation, Freehold, NJ, USA; blood group H substance was purified from mucin of porcine stomach (Sigma) as reported earlier [14]. E. europaea and G. simplicifolia ${\mathrm{I}-\mathrm{B}_{4}}_{4}$ lectins were purified according to procedures described previously $[15,16]$. Coffee bean $\alpha$-galactosidase was purified from commercial preparations of enzyme provided by Boehringer Mannheim Biochemicals, Indianapolis, IN, USA. It was purified by affinity chromatography on $N$-\&-aminocaproyl$\alpha$-D-galactopyranosylamine according to the procedure described by Harpaz et al. [17]. $\alpha$-L-Fucosidase was prepared from Trichomonas foetus cells, provided by American Type Culture Collection, Rockville, MD, USA. Cell-free extracts were prepared according to the procedure described earlier [18]. Briefly, $3 \mathrm{ml}$ of packed cells were suspended in $0.15 \mathrm{M} \mathrm{NaCl}$ and lysed by freezing/thawing three times at $-80^{\circ} \mathrm{C}$. The cellular debris was removed by centrifugation for $30 \mathrm{~min}$ at $17400 \times \mathbf{g}$ and the supernatant was dialysed against $\mathrm{H}_{2} \mathrm{O}$, lyophilysed and used for macrophage digestion.

\section{Enzyme assays}

$\alpha$-Galactosidase: the reaction mixture in a total volume of $450 \mu \mathrm{l}$ of Mcllvain's buffer $\mathrm{pH} 4.7$, contained $5.5 \mu \mathrm{M}$ $p$-nitrophenyl $\alpha$-D-galactopyranoside and varying amount of enzyme. The reaction was carried out by incubation at $37^{\circ} \mathrm{C}$ for $10 \mathrm{~min}$, stopped by addition of $0.7 \mathrm{ml}$ of solution containing $0.13 \mathrm{~m}$ glycine, $0.08 \mathrm{M}$ sodium carbonate and $0.06 \mathrm{M} \mathrm{NaCl}$, pH 10.7 , and the absorbance at $410 \mathrm{~nm}$ was determined. An appropriate control without enzyme was run in parallel, $\alpha$-L-Fucosidase: the assay was carried out with hog mucin $\mathrm{A}+\mathrm{H}$ substance as substrate. The loss of its serological activity with Ulex europaeus I lectin and the accompanying increase in reactivity with $D$. strammonium lectin were a measure of enzyme activity in $T$. foetus extracts. The loss of reactivity with Ulex I lectin was blocked by $0.1 \mathrm{M}$ L-fucose added to the reaction mixture containing enzyme. The reaction mixture in a final volume of $100 \mu \mathrm{l}$ of PBS contained $84 \mu \mathrm{g}$ of hog mucin $\mathrm{A}+\mathrm{H}$ substance, and the enzyme was incubated at $37^{\circ} \mathrm{C}$ for $3.5 \mathrm{~h}$. The reaction was stopped by boiling for $10 \mathrm{~min}$, and the reactivity of the hog mucin digest with lectins was tested by double-diffusion in $1 \%$ agar gel.

\section{Cells}

Macrophages were isolated by peritoneal lavage as described previously [19] from C57BL/6J female mice, age 4-6 weeks (Jackson Laboratories, Bar Harbor, ME, USA). Resident macrophages were obtained from normal, untreated mice while stimulated macrophages were obtained from animals four days after an intraperitoneal injection of $1 \mathrm{ml}$ sterile thioglycollate brewers medium (Difco, Detroit, MI, USA) according to the procedure reported earlier [7]. Activated macrophages were obtained from mice injected intraperitoneally with $70 \mu \mathrm{g}$ of Corynaebacterium parvum (Burroughs Wellcome Ltd., Research Triangle Park, NC, USA). Macrophages were collected after seven days by lavage. The IC-21 macrophage cell line was obtained from the American Type Culture Collection, Rockville, MD, USA. The cells were cultured in RPMI 1640 culture medium, supplemented with $10 \%$ heat-inactivated fetal calf serum, penicillin, streptomycin and glutamine. Harvested cells were washed twice with PBS free of $\mathrm{Ca}^{2+} / \mathrm{Mg}^{2+}$ and centrifuged at $300 \times \mathbf{g}$ for $15 \mathrm{~min}$. Cell suspension in PBS was taken for assays.

\section{Macrophage digestion with $\alpha$-galactosidase}

The reaction mixture in a final volume of $1 \mathrm{ml}$ PBS, with $5 \mathrm{mM}$ PMSF, contained between $7 \times 10^{6}$ and $18 \times 10^{6}$ stimulated macrophages, $1 \mathrm{mg}$ BSA and 12 to 40 units $\alpha$-galactosidase which had been dialysed overnight against PBS and concentrated on Centricon 10 (Amicon). The cells were incubated at $37^{\circ} \mathrm{C}$ for $4 \mathrm{~h}$ with occasional stirring. A control without enzyme was run in parallel. The reaction was stopped by centrifugation of the cells and decanting of the supernatant solution. The cells were washed twice with $3 \mathrm{ml}$ PBS containing $1 \mathrm{mg}$ BSA per $\mathrm{ml}$, counted in a Coulter counter, and used for lectin binding assays.

\section{Macrophage digestion with $\alpha$-D-galactosidase and $\alpha$-L-fucosidase}

The reaction was carried out in the same manner as with $\alpha$-galactosidase (above) except that the reaction mixture beside coffee bean $\alpha$-galactosidase, contained a concentrated extract of $\alpha$-L-fucosidase from $T$. foetus in an amount 
corresponding to approximately $1 \mathrm{ml}$ of packed cells. That the effect of $T$. foetus extracts on macrophages was due to $\alpha$-L-fucosidase and not to other glycosidases was shown by its inhibition with $0.1 \mathrm{M} \mathrm{L}$-fucose. The reaction mixture $(1 \mathrm{ml})$ also contained the following protease inhibitors: antipain $100 \mu \mathrm{g}$; aprotinin $10 \mu \mathrm{g}$; benzamidine, $100 \mu \mathrm{g}$; chymostatin, $100 \mu \mathrm{g}$; leupeptin, $10 \mu \mathrm{g}$ and pepstatin $50 \mu \mathrm{g}$. This mixture of inhibitors blocked the proteolytic activity of $T$. foetus extracts against Azocoll as a substrate. Proteolytic activity was determined according to manufacturer's instruction (Calbiochem).

\section{Trypsin digestion of IC-21 cells}

The cells were kept in plastic tubes in an ice-water bath and all solutions were at $0{ }^{\circ} \mathrm{C}$. Trypsin solutions were freshly prepared and their activity was determined with Azocoll (see above). The reaction mixture in a final volume of $0.8 \mathrm{ml}$ of PBS contained $9.4 \times 10^{6}$ cells and 2.5 or $10 \mu \mathrm{g}$ of trypsin-TPCK. Reaction mixtures were incubated at $25^{\circ} \mathrm{C}$ for $45 \mathrm{~s}$ and quenched by addition of $1 \mathrm{mg} \alpha_{2}$-macroglobulin in $0.1 \mathrm{ml}$ PBS and $10 \mu 10.2 \mathrm{M}$ PMSF. Control cells without enzyme were assayed in parallel and contained $1 \mathrm{mM}$ PMSF. Control and digested cells were washed four times with $3 \mathrm{ml}$ PBS, containing $1 \mathrm{~mm}$ PMSF and centrifuged each time at $700 \mathrm{~g}$ for $5 \mathrm{~min}$. Cells were counted in a Coulter counter, adjusted to the concentration required, and used for the binding studies. No loss of cells occurred after digestion with $2.5 \mu \mathrm{g}$ of trypsin compared with control cells. However, digestion with $10 \mu \mathrm{g}$ of trypsin resulted in a loss of $31 \%$ of the cells.

\section{Iodination and binding assays}

E. europaea and $G$. simplicifolia $\mathrm{I}^{-\mathrm{B}_{4}}$ lectins were iodinated according to the procedure described earlier $[7,20]$.
Binding assays were carried out as described previously [7]. For binding studies, radiolabelled lectins were diluted with unlabelled lectins in order to obtain the required specific radioactivity: $3.8 \times 10^{5}$ counts $\mathrm{min}^{-1} \mu^{-1}$ for E. europaea and $3.0 \times 10^{5}$ counts $\min ^{-1}{\mu \mathrm{g}^{-1}}^{-1}$ for G. simplicifolia $\mathrm{I}-\mathrm{B}_{4}$ isolectin. The number of cells used for binding, unless otherwise stated, was $1 \times 10^{5}$ per tube. Binding parameters: association constants $\left(K_{\mathrm{a}}\right)$ and number of receptors were determined from fitted curves plotted according to the Hill equation [21]. For binding, macrophages were pooled from two or three animals.

\section{Results and discussion}

Binding of ${ }^{125}$ I labelled E. europaea and ${ }^{125} I$

labelled G. simplicifolia I-B , lectins to $_{4}$

$\alpha$-galactosidase-treated stimulated macrophages

Stimulated macrophages, as opposed to nonactivated cells, express glycoconjugates that specifically bind GS I- $\mathrm{B}_{4}$ isolectin [3]. Treatment of stimulated murine macrophages with coffee bean $\alpha$-galactosidase at $37^{\circ} \mathrm{C}$ completely abolished specific binding of ${ }^{125} \mathrm{I}$ labelled $G$. simplicifolia $\mathrm{I}-\mathrm{B}_{4}$ isolectin to these cells (not shown). The absence of GS I- $\mathrm{B}_{4}$ binding provided a control for the removal of $\alpha$-D-galactosyl residues. Treatment of stimulated macrophages with $\alpha$-galactosidase did not abolish binding of the E. europaea lectin to these cells, but did reduce the affinity of binding approximately 23-fold (Fig. 1a, b, Table 1). From these results it may be concluded that $\alpha$-D-galactosyl residues present on stimulated macrophages constitute the receptor (or portion of the receptor) for both GS I-B ${ }_{4}$ and E. europaea lectins.

The question remains as to the nature of the remaining portion of the receptor responsible for binding the
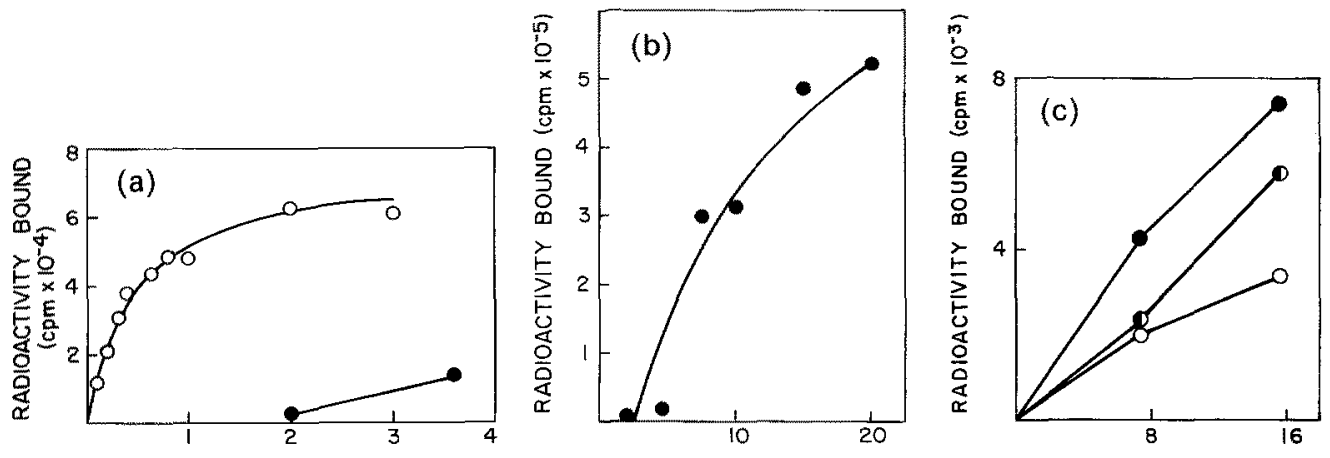

LECTIN ADDED $(\mu \mathrm{g})$

Figure 1. Specific binding of ${ }^{125} \mathrm{I}$ labelled $E$. europaea lectin to $\mathrm{TG}$-stimulated murine peritoneal macrophages. (a) $O$, untreated (the curve is compiled from [7]) and $\bullet, \alpha$-galactosidase digested. The number of cells, untreated and $\alpha$-galactosidase treated, used for binding measurements was $0.5 \times 10^{5}$ and $1.0 \times 10^{5}$, respectively. The specific radioactivity of lectin was $1.15 \times 10^{6} \mathrm{counts}^{\mathrm{min}}{ }^{-1} \mu \mathrm{gg}^{-1}$ and $3.77 \times 10^{5}$ counts $\min ^{-1} \mu \mathrm{g}^{-1}$ with untreated and $\alpha$-galactosidase treated cells, respectively. (b) $\bullet, \alpha$-Galactosidase treated cells. E. europaea lectin specific radioactivity was $3.77 \times 10^{5}$ counts $\min ^{-1} \mu \mathrm{g}^{-1}$. Note the difference in the ordinate scale between (a) and (b). (c) Cells were treated with $-\alpha$-galactosidase; $O, \alpha$-galactosidase and $\alpha$-L-fucosidase; $0, \alpha$-galactosidase and $\alpha$-L-fucosidase with $0.1 \mathrm{M}$ L-fucose. E. europaea lectin specific radioactivity was $2.0 \times 10^{5}$ counts $\min ^{-1} \mu \mathrm{g}^{-1}$. 
Table 1. Binding capacity and association constant $\left(K_{a}\right)$ of $E$. europaea lectin for murine, resident and TG stimulated, $\alpha-$ galactosidase digested macrophages.

\begin{tabular}{|c|c|c|}
\hline Macrophages & $\begin{array}{l}\text { Number of } \\
\text { binding sites } \\
\text { per cell }\end{array}$ & $K_{\mathrm{a}}$ \\
\hline Stimulated & $2.4 \pm 0.2 \times 10^{6}$ & $1.25 \times 10^{8} \mathrm{M}^{-1 \mathrm{a}}$ \\
\hline $\begin{array}{l}\text { Stimulated } \\
\alpha \text {-galactosidase } \\
\text { digested }\end{array}$ & $26.2+3.1 \times 10^{6}$ & $5.5 \times 10^{6} \mathrm{M}^{-1}$ \\
\hline Resident & $36.0 \times 10^{6 \mathrm{~b}}$ & $3.9 \times 10^{6} \mathrm{M}^{-1}$ \\
\hline
\end{tabular}

${ }^{a}$ The $K_{\mathrm{a}}$ for stimulated macrophages were calculated from the experimental data presented in [7], except that the Hill equation was used for calculation. ${ }^{b}$ Considering that resident macrophages constitute approximately $40 \%$ of the total cell population, this number of receptors if calculated per one macrophage would be $90 \times 10^{6}$.

lectin after removal of the $\alpha$-D-galactosyl residues. This can be rationalized on the basis of the complex carbohydrate binding properties of the E. europaea lectin. The best known inhibitor of this lectin is the blood group B tetrasaccharide containing both $\alpha$-D-galactosyl and $\alpha$-L-fucosyl groups: $\alpha$-D-Gal(1-3)[ $\alpha$-L-Fuc(1-2)] $\beta$-D-Ga1(1-3 or 4( $\beta$-D-GlcNAc. Removal of either of these terminal monosaccharide units produces a decrease in binding; nevertheless, the resulting trisaccharides still provide sufficient structure to be bound by the lectin. In the absence of terminal nonreducing $\alpha$-D-galactosyl residues, the $\alpha$-L-fucosyl group becomes a prerequisite for E. europaea lectin binding [22]. The decrease in binding affinity of $E$. europaea lectin to macrophages, following removal of $\alpha$-D-galactosyl units from their surface, strongly suggested that $\alpha$-L-fucosyl residues constitute part of the E. europaea lectin receptor on the murine macrophage surface. Indeed, treatment of stimulated macrophages with coffee bean $\alpha$-galactosidase together with $T$. foetus extracts containing $\alpha$-L-fucosidase caused a $55 \%$ decrease in binding of the E. europaea lectin to macrophages when compared with the binding of $E$. europaea lectin to macrophages treated solely with $\alpha$-galactosidase (Fig. 1c). That the reduced binding is caused by $\alpha$-L-fucosidase and not by other enzymes (glycosidases or proteases) was shown by blocking this effect by $0.1 \mathrm{M}$ L-fucose. In the presence of $0.1 \mathrm{M}$ L-fucose, Evonymus lectin binding was reduced by only $21 \%$ (Fig. 1c).

These results show that the carbohydrate epitope recognized by $E$. europaea lectin on TG-stimulated macrophages contains both $\alpha$-D-galactosyl and $\alpha$-L-fucosyl residues at its nonreducing terminus. This $\alpha$-L-fucosyl group must be linked to the nonreducing terminus of the oligosaccharide inasmuch as the E. europaea lectin does not bind $\alpha$-L-fucosyl residues linked to any internal sugar units of the oligosaccharide chain $[22,23]$. Low affinity binding cannot be due to oligosaccharides containing $\alpha$-D-galactosyl end groups because all $\alpha$-D-galactosyl residues were removed by treatment with $\alpha$-galactosidase, and the GS I- $\mathrm{B}_{4}$ isolectin did not bind to the $\alpha$-galactosidase-treated macrophages; furthermore, low affinity binding can be reduced by treatment with $\alpha$-L-fucosidase.

The possibility that terminal $\alpha$-L-fucosyl and $\alpha$-Dgalactosyl groups are located on different oligosaccharide molecules on the macrophage surface can be excluded on the following basis: both oligosaccharides, one with terminal $\alpha$-L-fucosyl group and the second with terminal $\alpha$-Dgalactosyl end groups show the same affinity toward the E. europaea lectin [22]. If these sugars are on separate molecules then digestion of macrophages with $\alpha$-D-galactosidase would not affect the binding affinity of the $E$. europaea lectin, but would only reduce the number of binding sites per cell. However, this is not the case.

The presence of $\alpha$-D-galactosyl and $\alpha$-L-fucosyl residues at the nonreducing terminus of the same oligosaccharide suggests a blood group B, or B-like, structure. Indeed, Handa et al. [24] isolated a glycolipid from rat granuloma and stimulated rat macrophages, that had a structure similar to that of blood group B active glycolipids present on human erythrocytes, except that the internal $\mathrm{N}$-acetylglucosamine unit was replaced by $\mathrm{N}$-acetylgalactosamine; in addition it was also a type 1 (1-3 linkage) oligosaccharide chain. This glycolipid, if present on the surface of murine macrophages, could account for the reactivity of E. europaea and GS I-B 4 lectins with stimulated macrophages, inasmuch as $E$. europaea lectin is able to react with both types 1 and 2 oligosaccharide chains.

There are some reports that two $\alpha$-L-fucose binding lectins (U. europaeus I and Lotus tetragonolobus) can influence the responsiveness of macrophages to migration inhibiting factor (MIF), presumably by lectin binding to $\alpha$-L-fucosyl receptors on the surface of the macrophage [25-31]. Despite these reports, no direct and convincing evidence for the specific binding of these lectins to the macrophage surface has been presented. Moreover, previous studies showed neither binding of FITC-labeled $U$. europaeus I lectin to the surface of stimulated macrophages, nor agglutination of these cells by $E$. europaea lectin [3, 4]. The presence of a fucosylated receptor in a blood group B or B-like structure can fully account for the lack of binding of $U$. europaeus I and L. tetragonolobus lectins to macrophages.

The same batch of stimulated macrophages used for the binding assay expressed a similar number of binding sites per cell for E. europaea and G. simplicifolia lectins: $2.4 \times 10^{6}$ and $3.6 \times 10^{6}$, respectively. However, there was a large difference in the number of receptors for E. europaea lectin before and after $\alpha$-D-galactosidase digestion. Untreated, stimulated macrophages contained approximately $2.4 \times 10^{6}$ high affinity receptors for $E$. europaea lectin, whereas $\alpha$-galactosidase digested macrophages contained an approximately 10 -fold larger number $\left(26.2 \times 10^{6}\right)$ of low affinity receptors. This indicates that only a fraction of the glycoconjugates which constitute a receptor for E. europaea 
lectin is $\alpha$-D-galactosylated. Murine macrophage membranes contain $\alpha$-D-galactosidase activity (unpublished data) and also contain a UDP-galactose:galactosyl- $\beta(1-4)$ $N$-acetylglucosamine $\alpha(1-3)$-galactosyltransferase [3, 32]. Whether the number of $\alpha$-D-galactosyl residues on the macrophage surface reflects a dynamic state caused by the competitive action of both enzymes remains to be determined.

Since $\alpha$-L-fucosyl residues have been suggested as a part of the receptor for several lymphokines [10-12], it seems that this sugar, present in an exposed position at the nonreducing termini of oligosaccharides, is well suited for this role. If this is the case, one should determine whether the agalacto- or galactosylated form of this fucoglycoconjugate might also serve as a lymphokine receptor.

\section{Binding of ${ }^{125} I$ labelled E. europaea lectin to resident macrophages}

It has been shown previously that resident murine macrophages do not bind the GS I-B B $_{4}$ isolectin [3]. Resident macrophages also do not display high affinity binding sites for E. europaea lectin (Fig. 2a); however, they do exhibit low affinity binding sites for this lectin with $K_{\mathrm{a}}=3.8 \times 10^{6} \mathrm{M}^{-1}$ as determined from the Hill equation (Fig. 2(b), Table 1). Thus, binding of ${ }^{125} \mathrm{I}$ labelled $E$. europaea lectin to resident macrophages shows the same characteristics as the binding of this lectin to $\alpha$-galactosidase-treated, stimulated macrophages in the following respects: (a) it has very close affinity, and (b) the number of receptors on resident and $\alpha$ galactosidase digested, stimulated macrophages is of the same order of magnitude (Table 1). The binding of $E$. europaea lectin to $\alpha$-galactosidase digested, stimulated macrophages is due to the presence of $\alpha$-L-fucosyl groups on their surface (see paragraph above). Because there are few or no $\alpha$-D-galactosyl residues on resident macrophages $[3,7]$, it is concluded that the receptor for E. europaea lectin present on resident macrophages contains terminal, nonreducing $\alpha$-L-fucosyl groups.

Thus, the only difference between resident and stimulated

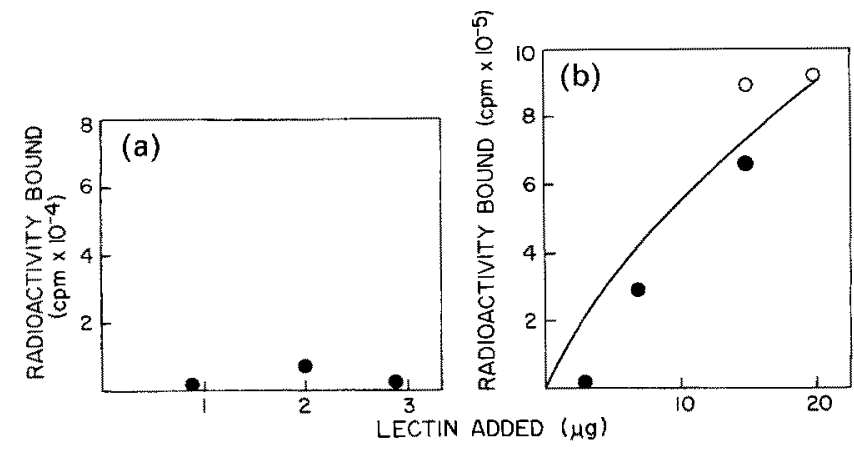

Figure 2. Specific binding of ${ }^{125} \mathrm{I}$ labelled E. europaea lectin to murine resident macrophages. $\bigcirc, 0$, From two different batches of cells. The number of cells taken for binding was $2 \times 10^{5}$. The lectin specific radioactivity was $3.29 \times 10^{5}$ counts $\min ^{-1} \mu \mathrm{g}^{-1}$. macrophages in the carbohydrate epitope for E. europaea lectin is the presence of $\alpha$-D-galactosyl residues on the stimulated macrophages. Accordingly, it would appear that $\alpha$-D-galactosyl residues are added to fucosylated oligosaccharides during the process of macrophage stimulation. The question remains as to whether the structural changes on fucoglycoconjugate(s) described in this paper are restricted solely to the carbohydrate epitope recognized by E. europaea

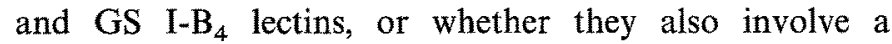
remaining portion of the glycoconjugate(s). The first possibility seems unlikely. Indeed, Mercurio and Robbins [6] observed an increase in GlcNAc $\beta(1-6)$ Gal branching of lactosaminoglycans from macrophages upon their stimulation/activation. $\alpha$-D-Galactosyl residues were added to these lactosaminoglycans as a result of macrophage stimulation/ activation. It was also reported (without data) that the glycopeptides they isolated contained fucose, but its position was not established.

In their report, Mercurio and Robbins [6] described the isolation of a tetrasaccharide from stimulated macrophages and proposed for it the structure: $\alpha-\mathrm{D}-\mathrm{Gal}(1-3) \beta-\mathrm{D}-$ Gal(1-4) $\beta$-D-GlcNAc(1-3)-D-Gal. This tetrasaccharide was obtained by endo- $\beta$-galactosidase digestion of pronase glycopeptides. From these studies, the most likely structure for an $\alpha$-D-galactosyl containing tetrasaccharide is $\alpha$-D$\operatorname{Gal}(1-3)[\alpha-\mathrm{L}-\mathrm{Fuc}(1-?)] \beta$-D-Gal(1-3 or 4$) \beta$-D-GlcNAc/ $\beta$-DGalNAc. What are the possible reasons for this discrepancy? In these studies the whole cell surface is being probed, so the structure proposed here may be located on glycoproteins or glycolipids, whereas Mercurio and Robbins [6] isolated the tetrasaccharide solely from glycopeptides. However, it is also possible that the oligosaccharide structure proposed here may be present on both glycolipids and glycoproteins. In the event that this fucosylated oligosaccharide is present on glycoprotein molecules, it is necessary to assume that glycoproteins contain both fucosylated and nonfucosylated oligosaccharides in order to account for the discrepancy between our result and those reported earlier and [6]. The Escherichia freundi endo- $\beta$-galactosidase, used in the digestion of glycopeptides by Mercurio and Robins, does not cleave fucosylated oligosaccharides. Indeed, Fukuda [33] has shown that this enzyme had little activity toward lacto- $N$-fucopentaose I which has an $\alpha$-L-fucosyl group at its nonreducing terminus.

All immunological studies carried out on the role of $\alpha$-L-fucosyl residues in the possible interaction of macrophage with lymphokines, have indicated the presence of $\alpha$-L-fucosyl residues on stimulated macrophages [10-12]. However, no attention has been paid to the possible existence of fucosyl residues on resident macrophages. These results may stimulate further studies which may shed new light on the role of $\alpha$-L-fucosylated glycoconjugates on resident and stimulated macrophages, as well as on the role of structural changes which take place on these glycoconjugates during macrophage stimulation/activation. 


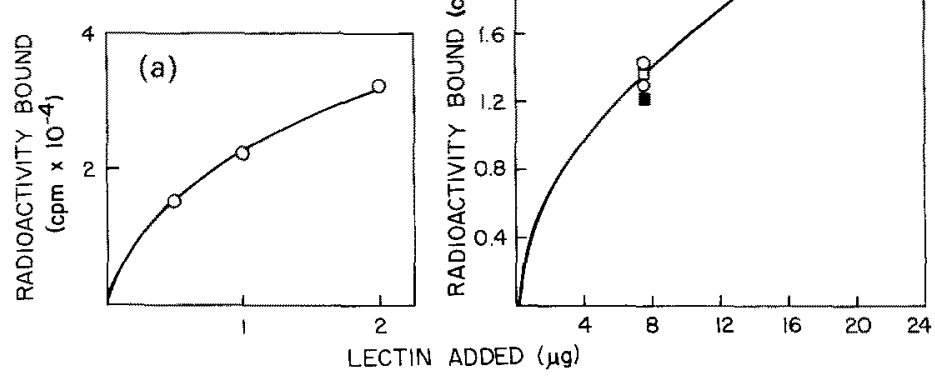

Figure 3. Specific binding of (a) ${ }^{125} \mathrm{I}$ labelled $E$. europaea lectin and (b) ${ }^{125} \mathrm{I}$ labelled $G$. simplicifolia I-B4 lectin to macrophage cell line IC-21: $O$, untreated; $\square$, treated with $2.5 \mu \mathrm{g}$ trypsin; and $\mathbf{E}$, treated with $10 \mu \mathrm{g}$ trypsin. Specific radioactivity of E. europaea and $G$. simplicifolia $I-B_{4}$ lectin was $2.4 \times 10^{5}$ and $10^{5}$ counts $\min ^{-1} \mu \mathrm{g}^{-1}$, respectively.

Table 2. Binding capacity and association constant $\left(K_{\mathrm{a}}\right)$ of $E$. europaea and $G$. simplicifolia $1-B_{4}$ lectins to $T G$ stimulated macrophages and IC-21 macrophage cell line.

\begin{tabular}{llllll}
\hline \multirow{2}{*}{\begin{tabular}{l} 
Cells \\
\cline { 5 - 6 }
\end{tabular}} & $\begin{array}{l}\text { Number of } \\
\text { binding sites } \\
\text { per cell }\end{array}$ & $\begin{array}{l}K_{\mathrm{a}} \\
\left(\mathrm{M}^{-1}\right)\end{array}$ & $\begin{array}{l}\text { Number of } \\
\text { binding sites } \\
\text { per cell }\end{array}$ & $\begin{array}{l}K_{\mathrm{a}} \\
\left(\mathrm{M}^{-1}\right)\end{array}$ \\
\hline $\begin{array}{l}\text { TG stimulated } \\
\text { macrophages }\end{array}$ & $3.8-4.8 \times 10^{6}$ & $9.2 \times 10^{7}$ & $2.0-16.8 \times 10^{6}$ & $7.5 \times 10^{6}$ \\
$\begin{array}{l}\text { IC-2 macrophage } \\
\text { cell line }\end{array}$ & $4.4 \times 10^{6}$ & $6.7 \times 10^{7}$ & $19.7-28.0 \times 10^{6}$ & $4.1 \times 10^{6}$ \\
\hline
\end{tabular}

${ }^{a}$ Compiled from Petryniak et al. [7].

Binding of ${ }^{125} I$ labelling E. europaea and ${ }^{125} I$

labelled $G$. simplicifolia lectins to the IC-21

macrophage cell line (Fig. 3)

The IC-21 cells, which share characteristics of activated macrophages [34, 35], express a large number of binding sites for the GS I-B $\mathrm{B}_{4}$ and E. europaea lectins. We found $4.4 \times 10^{6}$ and from 19.7 to $28.0 \times 10^{6}$ binding sites per cell for the E. europaea and GS I-B ${ }_{4}$ lectins, respectively (Table 2). The approximate $K_{\mathrm{a}}$ for binding E. europaea and GS I-B 4 lectins were $6.7 \times 10^{7} \mathrm{M}^{-1}$ and $4.1 \times 10^{6} \mathrm{M}^{-1}$, respectively (Table 2). These values are very close to those found for TG stimulated macrophages. The receptor(s) for the E. europaea and GS I-B 4 lectins on IC-21 cells is identical to the receptor on TG-stimulated peritoneal macrophages in the following respects: (a) the IC-21 cell line binds both lectins; (b) the cell line contains terminal $\alpha$-D-galactosyl residues; this conclusion is derived both from the specificity

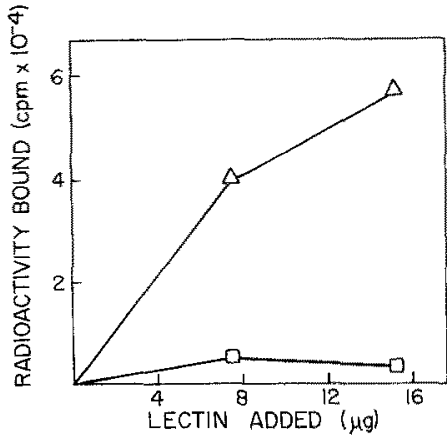

Figure 4. Specific binding of ${ }^{125} \mathrm{I}$ labelled $G_{\text {. }}$ simplicifolia lectin to IC-21 macrophage cell line: $\triangle$, untreated; $\square$, treated with coffee bean $\alpha$-galactosidase. The number of cells used for binding was $1.8 \times 10^{5}$. The specific radioactivity of lectin was $2.27 \times 10^{5}$ counts $\min ^{-1} \mu \mathrm{g}^{-1}$.

of the GS I-B $\mathrm{B}_{4}$ isolectin and from the fact that digestion of these cells with affinity-purified $\alpha$-D-galactosidase abolished

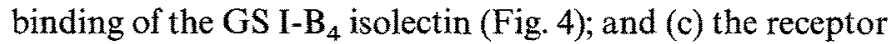
is also trypsin resistant (Fig. 3b). The only difference we found was that glycoconjugates containing $\alpha$-D-galactosyl groups on IC-21 cell line were less stable during prolonged incubation at $37^{\circ} \mathrm{C}$; incubation of IC-21 cells at $37^{\circ} \mathrm{C}$ for $4 \mathrm{~h}$ produced a $70 \%$ loss of the number binding sites for GS $\mathrm{I}-\mathrm{B}_{4}$ isolectin whereas, under the same conditions, there was no decrease in binding capacity for GS I-B $\mathrm{B}_{4}$ on TG stimulated macrophages. The presence of $\alpha$-D-galactosyl containing glycoconjugate receptor(s) on the IC-21 macrophage cell line, as well as on murine peritoneal cells and on peritoneal exudate cells, which are predominantly macrophages, indicates that this glycoconjugate is of macrophage origin.

Binding of ${ }^{125} I$ labelled E. europaea and ${ }^{125} I$

labelled $G$. simplicifolia $I-B_{4}$ lectins to Corynaebacterium-activated macrophages (Fig. 5)

Activation of murine macrophages with Corynaebacterium caused an approximately twofold increase in the binding capacity for both of the above lectins when compared with resident macrophages, which display few galactosyl residues (some batches of resident macrophages do not display detectable $\alpha$-galactosyl residues). This explicit increase in galactosyl residues on $C$. parvum activated macrophages is low when compared with TG stimulated macrophages. However, in these experiments mice were injected with low amounts of bacteria ( $70 \mu \mathrm{g}$ per mouse). The dynamics of the expression of these residues on $C$. parvum activated macrophages would require time- and dose-dependent studies. Thus, this phenomenon of changes observed in cell surface glycoconjugates is not restricted to TG stimulated macrophages: it also occurs in macrophages activated by C. parvum and in the activated IC-21 cell line. 


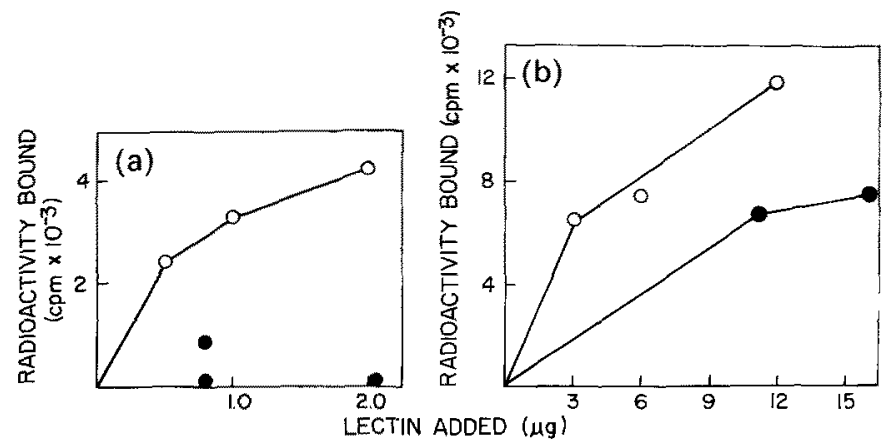

Figure 5. Specific binding of (a) ${ }^{125} \mathrm{I}$ labelled $E$. europaea lectin and (b) ${ }^{125}$ I labelled $G$. simplificolia lectin to: G, C. parvum activated macrophages; and $\bullet$, resident macrophages. E. europaea and $G$. simplicifolia lectins specific radioactivity were $2.43 \times 10^{5}$ and $2.62 \times 10^{5}$ counts $\min ^{-1} \mu \mathrm{g}^{-1}$. respectively.

\section{Acknowledgments}

I wish to thank Dr. Irwin J. Goldstein for critical review of the manuscript. This work was supported by Grant CA 20424 from the National Institutes of Health.

\section{References}

1. Adams DO, Hanna MG Jr. (eds) (1984) Macrophage Activation. New York: Plenum Press.

2. Van Furth R (ed.) (1980) Mononuclear Phagocytes. Functional Aspects. Parts $I$ and II. The Hague: Nijhoff.

3. Maddox DE, Shibata S, Goldstein IJ (1982) Proc Natl Acad Sci USA 79:166-70.

4. Petryniak J, Dus D, Podwinska J (1983) Eur J Immunol 13:458-64.

5. Mercurio AM, Schwarting GA, Robbins PW (1984) $J$ Exp Med 160:1114-25.

6. Mercurio AM, Robbins PW (1985) J Immunol 135:1305-12.

7. Petryniak J, Huard TK, Nordblom GD, Goldstein IJ (1986) Arch Biochem Biophys 244:57-66.
8. Petryniak J, Huard TK, Goldstein IJ (1987) J Cell Biochem Supplement 11D:155.

9. Maddox DE, Goldstein IJ, LoBuglio AI (1982) Cell Immunol $71: 202-7$

10. Amsden A, Ewan V, Yoshidsa T, Cohen S (1978) $\mathrm{J}$ Immunol 120:542-8.

11. Churchill HW, Wong C (1980) Cell Immunol 55:490-8.

12. Remold HG (1973) J Exp Med 138:1065-76.

13. Takacs B, Staehli C (1987) J Immunol 138:1999-2007.

14. Morgan WTJ, King HK (1943) Biochem $J$ 37:640-51.

15. Petryniak J, Janusz M, Markowska E, Lisowska E (1981) Acta Biochim Polon 28:267-73.

16. Delmotte FM, Goldstein IJ (1980) Eur J Biochem 112:219-23.

17. Harpaz N, Flowers HM, Sharon N (1974) Biochim Biophys Acta 341:213-21.

18. Watkins WM (1966) Methods Enzymol 8:700-11.

19. Wicha MS, Huard TK (1983) Exp Cell Res 143:475-9.

20. Hunter WM, Greenwood FC (1962) Nature 194:495-6.

21. Hill $\mathrm{R}$ (1925) Proc $R$ Soc B 100:419.

22. Petryniak J, Goldstein IJ (1986) Biochemistry 25:2829-38.

23. Petryniak J, Pereira MEA, Kabat EA (1977) Arch Biochem Biophys 178:118-34.

24. Handa E, Handa S, Konno K, Yamakawa T (1978) J Biochem (Tokyo) 83:85-90.

25. Braatz AJ, Redmon LW, Holden HW (1980) In Biochemical Characterization of Lymphokines (deWeck AL, Kristensen $\mathrm{F}$, Landy M, eds), p. 87. New York: Academic Press.

26. Fahlbush B, Wollweber L, Drosller K, Scherbaum T, Zschieschie W (1982) Immunobiology 162:251-64.

27. Leu RW, Whitley SB, Herriot T, Huddeston DJ (1980) Cell Immunol 52:414-28.

28. Newman W, Bloom BR, Satoh P (1976) Cell Immunol 227:334.

29. Poste G, Kirsh R, Fogler WE, Fidler IJ (1979) Cancer Res 39:881-92.

30. Poste G, Kirsh R, Fidler IJ (1979) Cell Immunol 44:71-88.

31. Poste G, Allen H, Matta KL (1979) Cell Immunol 44:89-98.

32. Sheares BT, Mercurio AM (1987) J Immunol 139:3748-52.

33. Fukuda MN (1980) J Biol Chem 256:3900-5.

34. Maeul J, Defendi V (1971) J Exp Med 134:335-50.

35. Walker WS, Demus A (1975) J Immunol 114:765-9. 